\begin{tabular}{c} 
Volume and Issues Obtainable at Center for Sustainability Research and Consultancy \\
Journal of Business and Social Review in Emerging Economies \\
ISSN: 2519-089X (E): 2519-0326 \\
Volume 5: No. 2, December 2019 \\
ᄃSRᄃ \\
Journal homepage: www.publishing.globalcsrc.org/jbsee \\
\hline
\end{tabular}

\title{
Management Implementation of Batik SME Strategy in JAMBI
}

\author{
${ }^{1}$ M. Tony Nawawi, ${ }^{2}$ Zahrida Wiryawan, ${ }^{3}$ Rodhiah \\ ${ }^{1}$ Tarumanagara University, Jakarta, Indonesia: tonyn@fe.untar.ac.id \\ ${ }^{2}$ Tarumanagara University, Jakarta, Indonesia \\ ${ }^{3}$ Tarumanagara University, Jakarta, Indonesia
}

\begin{tabular}{l} 
ARTICLE DETAILS \\
\hline History \\
Revised format: November 2019 \\
Available Online: December 2019
\end{tabular}

\section{Keywords}

Strategy Management, Internal,

External, SWOT

\section{JEL Classification:}

L10, M11, M19

\begin{abstract}
This study aims to determine the competitive advantage of SMEs, which are associated with the management process strategy of internal and external sides of SMEs.Conducted on Jambi batik area SMEs which were selected in a sample by purposive sampling. Data collection was done by using observation, interviews and FGD on 6 SMEs selected by purposive sampling.Research analysis is carried out qualitatively, by implementing the results of SWOT analysis. Which aims to develop strategies that must be done by SMEs in making decisions to excel in competition.Identified 24 strategies that need to be done by SMEs in running the business optimally, so that they can face competition with other business subsectors and Jambi batik SMEs can continue to have competitive advantages.
\end{abstract}

(C) 2019 The authors, under a Creative Commons AttributionNonCommercial 4.0

Corresponding author's email address: tonyn@fe.untar.ac.id

Recommended citation: Nawawi, M. T., Wiryawan, Z. and Rodhiah, (2019). Management Implementation of Batik SME Strategy in JAMBI. Journal of Business and Social Review in Emerging Economies, 5 (2), 379-388

DOI: $10.26710 /$ jbsee.v5i2.816

\section{Introduction}

One of the assets that gives value to economic progress in Indonesia is SMEs. The existence of SMEs not only be able to accommodate the absorption of labor which is quite a lot, but also a source of revenue to the public welfare.For this reason, SMEs need to get great attention from various parties. Both from the business actors themselves, the government, and the society.

Business actors need to pay attention to strategic management in achieving organizational goals that have been set. Strategic management allows organizations to be more proactive than reactive in shaping their own future; and exercise control over his own destiny (David, 2003).Strategic management consists of analysis, decisions and actions taken by an organization to create and maintain competitive advantage. Through the process of strategic management of external and internal factors, an organization can identify critical threats and opportunities in its competitive environment.Examining how competition in the environment might evolve, what implications evolution has for threats and opportunities of an organization, identifying organizational strengths and weaknesses based on SWOT analysis (Barney and Hesterly, 2006).SWOT analysis is a simple but powerful tool to measure the ability of organizational resources and deficiencies, market opportunities, and external threats to its future "(Thompson et al., 2007). SWOT Analysis is a strategic planning tool used to evaluate the strengths, weaknesses, opportunities and threats of an organization.Providing information that is very helpful in matching organizational resources and capabilities with a competitive environment. 
An organization needs to harmonize internal activities with external reality to be successful. The SWOT analysis provides a framework for analyzing internal strengths and weaknesses and external opportunities and threats. Helps minimize weaknesses and take advantage of the best opportunities available.The results of, considering external and internal factors are very important because they clarify the world in which the business or unit operates, making it possible to get a better picture for the desired future (Pahl and Richter, 2009: Hill and Westbrook (1997); Cojanu and Bilbor , 2007: 164; Sarbah and Otu-Nyarko, 2014:236-237; Kew and Stredwick, 2010; Sevkli, 2012: 15; Brad and Brad, 2015. Weihrich (1982).For this reason the research was conducted on batik UKM in Jambi, so that a comprehensive assessment of external and internal factors can be determined to determine the competitive position of batik SMEs today and the potential growth of SMEs.

The problems that will be examined in this research are: How is the most appropriate strategy implementation for Jambi batik SMEs, by conducting internal analysis (Strength, Weaknesses) and external (Opportunities, Threaths).The research objective is to analyze the strategies that need to be done by batik SMEs to excel in competition.

\section{Literature Review}

Management process strategies was evaluation with internal and external condition in SME'S done and implementations. With the internal and external factors that can be affect in their activities. The evaluated process by SWOT. Kotler (2012), SWOT analysis is is an evaluation of the overall strengths, weaknesses, opportunities, and threats. "Through this analysis, SMEs can analyze patterns of strengths and weaknesses, and business units do not have to correct all their weaknesses or utilize all their strengths In developing the strategy, it must first identify various factors that systematically maximize strengths and opportunities, and minimize weaknesses and threats. This analysis is called SWOT analysis, with definitions shown in Tables 1 and 2. (Zimmerer, Scarborough \& Wilson; 2008).

Table 1. Identification of Strengths \& Weaknesses of a Company

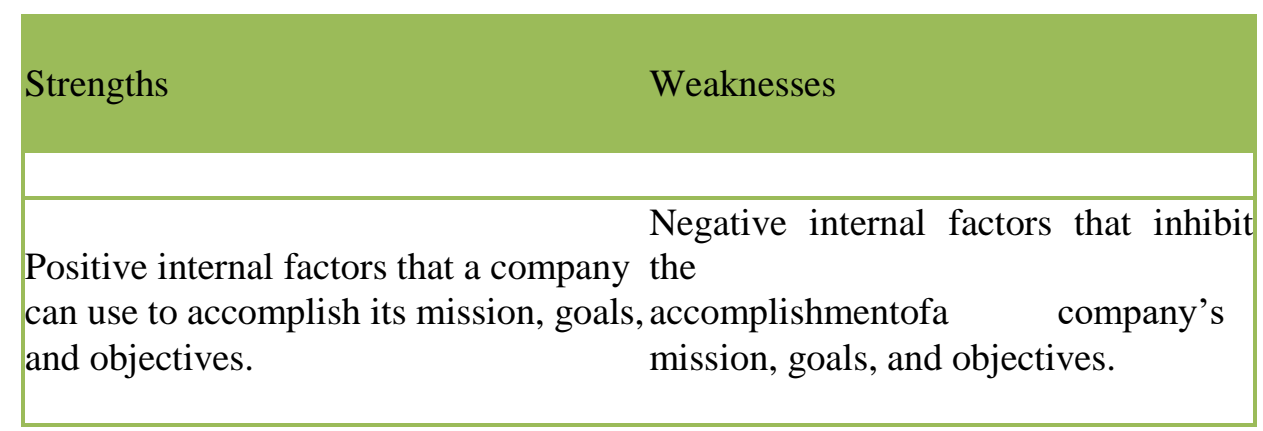

Identification of Company Opportunities and Threats

\begin{tabular}{|ll|}
\hline Opportunities & Threats \\
\hline Positive external option that a firm can & $\begin{array}{l}\text { Negative external forces that inhibit } \\
\text { a company's ability to achieve it } \\
\text { exploit to accomplish its mission, goals, } \\
\text { And objectives. } \\
\text { goals, and objectives. }\end{array}$ \\
\hline
\end{tabular}

\section{Research Methodology}

The research was carried out in February to September 2018. The locations of the study is in some batik SMEs such as Kampung Tengah, Ulu Gedong, Tanjung Pasir, which are traditionally managed in Jambi City. 4 SMEs were selected as samples by purposive sampling, namely by being based on businesses in the category of SMEs (Small Medium Enterprises). The production process of jambi batik is still using conventional methods, not using modern equipment / machinery. This research activity includes: 


\section{Tabel 2: Research Activities}

\begin{tabular}{|c|c|c|c|}
\hline Year I & Type of activity & Activities & Activity Results \\
\hline \multirow{7}{*}{$\begin{array}{l}\text { Activities } \\
\text { carried out }\end{array}$} & $\begin{array}{l}\text { Market Survey of Jambi } \\
\text { batik }\end{array}$ & $\begin{array}{l}\text { Observation,draft } \\
\text { interview }\end{array}$ & \multirow{7}{*}{$\begin{array}{l}\text { Primary data and } \\
\text { secondary data to find } \\
\text { out the strengths, } \\
\text { opeaknesses, } \\
\text { opportunities } \\
\text { threats } \\
\text { of SME's batik Jambi }\end{array}$} \\
\hline & Literature Study & SWOT & \\
\hline & Observation and interview & $\begin{array}{l}\text { Record the location of } \\
\text { batik } \\
\text { SMEs } \\
\text { Record the Problems of } \\
\text { SMEs }\end{array}$ & \\
\hline & Field survey and FGD to & Develop a marketing & \\
\hline & $\begin{array}{l}\text { MSMEs, Koperindag } \\
\text { service, } \\
\text { material distributors and }\end{array}$ & $\begin{array}{l}\text { strategy design and } \\
\text { SWOT } \\
\text { analysis }\end{array}$ & \\
\hline & consumers & & \\
\hline & $\begin{array}{l}\text { Designing a SWOT strategy } \\
\text { model }\end{array}$ & $\begin{array}{l}\text { Implementation of } \\
\text { Evaluation results. Pilot } \\
\text { project: to develop a } \\
\text { strategy }\end{array}$ & \\
\hline
\end{tabular}

Various sources can assist in the preparation of research that will later be prepared and processed to strengthen the analysis. According to Lofland and Lofland in (Moleong, 2002), the main data sources in qualitative research are words and actions while the rest are additional data such as documents and others.

\subsection{Data sources}

\subsubsection{Primary Data Source}

Primary data is data obtained from the first source either from individuals by interviews or filling out questionnaires that are usually done by researchers (Umar Husein: 2000). Primary data in this study were obtained through indepth interviews and direct observation on batik SMEs Jambi.
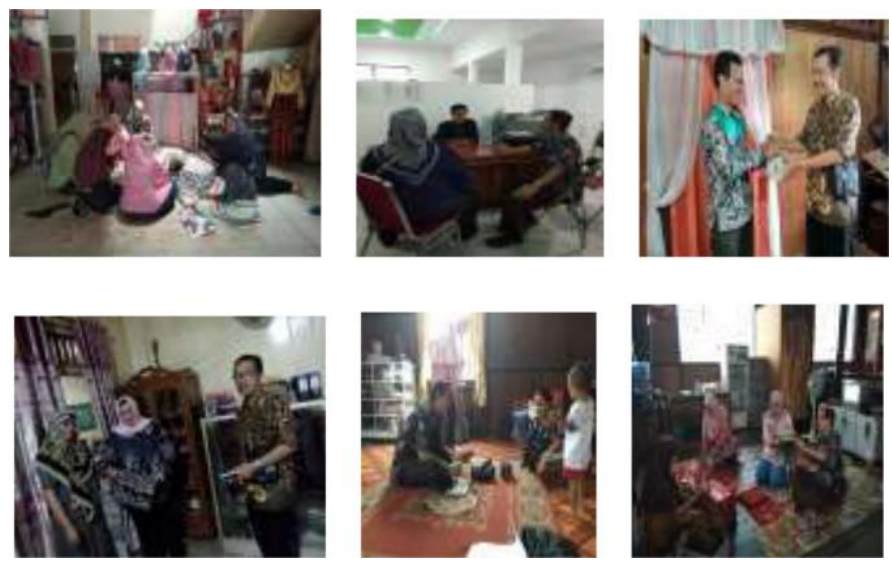

Figure 1.Overview of Respondents

\subsubsection{Secondary Data Sources}

Secondary data is research data obtained by researchers indirectly or through a media intermediary (obtained and recorded by other parties). The data used in this study are data from literature study, Jambi Koperindag Office 


\subsection{Analysis Method}

To answer the problems faced by batik SMEs that have been selected as research samples, the following analytical methods are used: SWOT analysis is an analysis carried out by describing the implementation of marketing strategies through strengths, weaknesses, opportunities, and threats. The Strength- Weakness-Opportunity-Threat (SWOT) matrix is an important tool help managers develop four types of strategies, namely SO (strerngthsopportunities), WO (weakness-opportunities), ST (strengths-threats), WT (weaknesses-threats)), ST (strengthsthreats), dan WT (weaknesessthreats).

\section{Results and Discussion}

Analysis of UKM Batik Jambi Profile Based on data from the Koperindag(Department of Cooperatives, UMKM, Industry and TradeOffice)of Jambi Province One of the centers of Jambi batik craft is located on Jalan KH M. Ja'Far MudungLaut, Seberang, Jambi. Based on the survey results to the Department of koperindag, the attached data on Jambi batik SMEs in the province up to 2017, shows the number of batik by approximately 80 craftsmen. But only about 55 craftsmen are still active. The collection of results of these craftsmen is mostly displayed and sold to batik studios. As a craft center, they have a community called 'Koperasi Kajang Lako' which is chaired by Mrs. Ida. It is this cooperative that has duties, among others; fostering members (UKM), marketing batik products together, holding / participating in exhibitions, improving HR skills and initiating seeking government support.The atmosphere outside and inside the studio and the types of batik offered are:
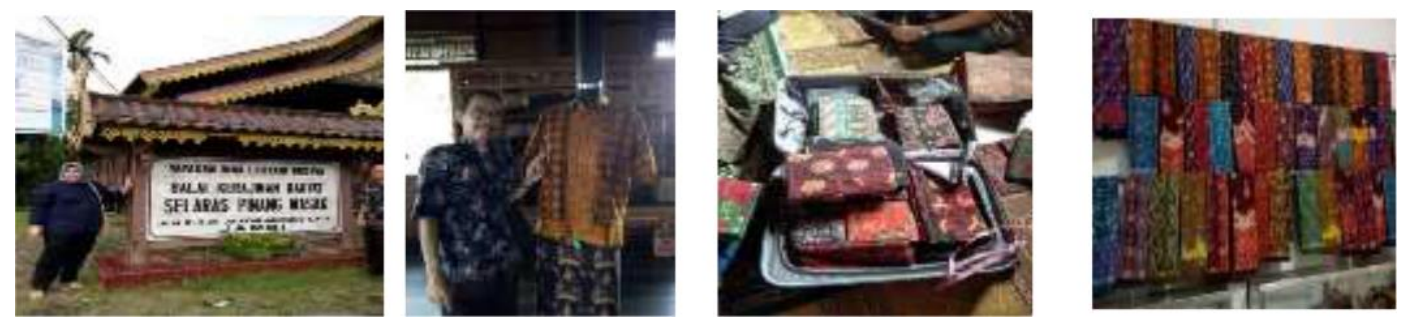

\section{Figure 2. Centra Batik Jambi}

\section{Implementation and Evaluation of Strategy Models}

Through the results of the assessment of strengths, weaknesses, opportunities and threats After knowing the position of the Batik Jambi UKM at this time, then the SME strategy factors were developed using the SWOT matrix (Table 5.1).

Table 3 Development of Competitive SMEs Batik Strategies

\begin{tabular}{|c|c|c|}
\hline Internal Factor & $\begin{array}{l}\text { Strengths(S) } \\
\text { 1. Jambi has a central business } \\
\text { unit of batik centered in the } \\
\text { studio } \\
\text { 2. Having long batik skills and } \\
\text { descending } \\
\text { 3. Good quality of batik } \\
\text { 4. Batik motifs that depict the } \\
\text { historical kingdom of Malay } \\
\text { and quite a lot } \\
\text { 5. Batik coloring is a natural } \\
\text { business } \\
\text { 6. Good relationships with } \\
\text { customers } \\
\text { 7. Jambi batik enthusiasts who } \\
\text { have started from outside the } \\
\text { island of Sumatra }\end{array}$ & $\begin{array}{l}\text { Weakness(W) } \\
1 \text { There has been no collaboration } \\
\text { between craftsmen and CRS and } \\
\text { banks } \\
\text { 2.Limitedcapital } \\
\text { 3. Many still use traditional } \\
\text { methods so that it takes longer } \\
\text { 4. The cost of raw materials is } \\
\text { quite expensive and causes high } \\
\text { selling prices that are difficult to } \\
\text { compete with Javanese batik } \\
\text { 5. HR is inadequate to produce } \\
\text { large scale } \\
\text { 6. Do not cooperate with } \\
\text { dressmakers } \\
\text { 7. Difficulties in innovation for } \\
\text { women's clothing ready for use }\end{array}$ \\
\hline $\begin{array}{l}\text { Opportunity (O) } \\
1 \text { LN market demand for batik } \\
\text { 2. There are local government }\end{array}$ & $\begin{array}{l}\text { S-O } \\
\text { 1. Empowering craftsmen } \\
\text { groups }\end{array}$ & $\begin{array}{l}\mathrm{W}-\mathrm{O} \\
1 . \text { Bring it closerbanking and } \\
\text { programslocal government }\end{array}$ \\
\hline
\end{tabular}




\begin{tabular}{|c|c|c|}
\hline $\begin{array}{l}\text { facilities: batik houses or } \\
\text { studios, exhibition sponsors, } \\
\text { assistance and coaching. } \\
\text { 3. Modern technology for } \\
\text { increase market expansion } \\
\text { 4. Centra- batik which is } \\
\text { centered on the Batanghari } \\
\text { River region, can become a } \\
\text { tourist attraction and attract } \\
\text { tourists to visit } \\
\text { 5. The market for batik is } \\
\text { increasingly widespread }\end{array}$ & $\begin{array}{l}\text { Batik to be more optimal } \\
\text { 2. Increasing guidance on } \\
\text { young genres to learnbatik } \\
\text { 3. Innovating more modern } \\
\text { motives } \\
\text { 4. Using modern technology to } \\
\text { increase production } \\
\text { 5. Maintaining product quality } \\
\text { 6. Develop a business using } \\
\text { capital assistance from } \\
\text { government } \\
\text { 7. Government assistance in } \\
\text { promoting batik center }\end{array}$ & $\begin{array}{l}\text { assistance for strengthening of } \\
\text { business capital } \\
\text { 2.Improve skills \& training for } \\
\text { workers embroidery } \\
\text { 3. Conduct training for employees } \\
\text { 4.Recruiting } \\
\text { 5. Cooperate with experts } \\
\text { wholesalers batik } \\
\text { 6. Increase promotion by making } \\
\text { advertisements on the internet } \\
\text { 7.Offer a products to } \\
\text { organization or groups work }\end{array}$ \\
\hline $\begin{array}{l}\text { Threat }(\mathrm{T}) \\
\text { 1. Competitors who imitate the } \\
\text { Jambi motif with low-priced } \\
\text { products } \\
\text { 2. Overseas competitors with } \\
\text { modern product concepts } \\
\text { 3. Price of raw materials for } \\
\text { making batik is high } \\
\text { 4. Variable models of finished } \\
\text { products of batik from Java }\end{array}$ & $\begin{array}{l}\text { S-T } \\
\text { 1. Give protection to creativity } \\
\text { Batik products } \\
\text { 2. Provide information on } \\
\text { quality standards } \\
\text { products } \\
\text { 3. Improve quality service to } \\
\text { customer } \\
\text { 4.Conduct business partnerships } \\
\text { 5. Improving models of finished } \\
\text { products that are more creative } \\
\text { and innovative }\end{array}$ & $\begin{array}{l}\text { W-T } \\
\text { 1. Improve infrastructure area } \\
\text { 2. Develop policies for } \\
\text { Development of tourist cities } \\
\text { along the Batang Hari river } \\
\text { 3. Increase capital with make a } \\
\text { loan to government through State- } \\
\text { owned Enterprise (BUMN) } \\
\text { 4. Increase the use of promotional } \\
\text { media more dispersed } \\
\text { 5. Adding mels } \\
\text { distribution channels }\end{array}$ \\
\hline
\end{tabular}

\section{$5.1 \quad$ S-O Strategy}

The S-O strategy column is a strategy that uses power to take advantage of opportunities.

Some strategies that can be used regarding this strategy are:

- Empowering Batik craftsmen groups to be more optimal Geographically the business group is centralized in the neighboring city, TelukTeluk. This partnership can be easily collected, monitored and evaluated for the existence and development of its business. Problems faced by craftsmen can be easily resolved. Considering this group is centralized in the batik studio.For this reason the local government must continue to monitor the existence of each permit group to be more advanced and developed.

- Improving guidance for the younger generation to learn batik Sustainability of batik SMEs is very dependent on the next generation. The tendency of Jambi batik comes from generation to generation, and some have even started a business from the third generation. However, not all batik makers have future generations.For that, the existence of homeschooling for free can be an activist for the younger generation to love to make batik.

- Innovating more modern motives the tendency of monotonous batik motifs and every craftsman is less innovative about the motives made. This makes consumers become saturated. For this reason, a new motive effort is needed which combines classic motifs and modern motifs.Like the sanggat boat motif, peacock, glass plate, broken durian can be made more modern with coloring that is adjusted to the current consumer tastes.

- Using modern technology to increase production the batik production process is carried out in a simple, traditional way so that it is more time consuming. If craftsmen can use more modern technology, it can save working time.Likewise with the design, the combination of colors. To be more attractive, you can use computerized software or software, including marketing activities. Although some pematikhave been able to do online marketing, but it has not been done optimally. Need to be done further learning. 
- Maintaining product quality management's attention to quality is now good enough, so what needs to be improved is socialization to lower level employees, especially for employees who are directly related to production.This can be done by utilizing the existing organizational structure until the company policy is truly understood and implemented in the field. Equally important is to provide an explanation of the importance of maintaining product quality and the reasons why employees must do so.In this way, it is expected that employees can maintain product quality at each stage of the production process on the basis of their own awareness. Likewise, the cohesiveness between the drivers is also needed to maintain the quality image of batik from Jambi.

- Developing a business using capital assistance from the government in general, the problem of SMEs in developing a business is capital, the difficulty of getting fresh funds is almost experienced by all batik craftsmen. Meanwhile for bank credit applications require collateral. Which sometimes does not have craftsmen. So that the hope of the government can help fresh funds with soft interest or from CSR programs of private companies.

- Increasing procurement promotion in the center of batik the group of Jambi batik craftsmen have been seen, in Sanggar batik.(batik studio) But the existence of the studio has not fully touched the attention of many people. So that this batik center needs to be published its existence through various promotions can improve the center of batik.Like holding various events. Or other promotions to attract the attention of the public visit the batik center. Along the batik center road, we need to install a sapandu banner. So that the existence of batik center can be known.

\subsection{W-O Strategy}

The W-O strategy column is the strategy used by companies to overcome the weaknesses of the company by taking advantage of opportunities. Some strategies that can be done are:

- Bring closer to banks and local government programs and assistance to strengthen business capital.

People's Business Credit (KUR) socialization, requirements for applying for business loans need to be made to SMEs, especially most SMEs do not understand the terms and conditions of credit application.KUR socialization, requirements for applying for business loans need to be made to SMEs, especially most SMEs do not understand the terms and conditions of credit application.

- Perform efficiency to reduce the company's operating costs the high selling price is closely related to the costs incurred during the production process, ie the higher the cost of production per unit of product, the sale price will be higher.This resulted in the difficulty of the product to enter the market, coupled with the economic conditions of the people who were generally still in a crisis. The high selling prices of these products can be overcome by making efficiency during the production process.Direct efficiency can be done by reducing costs that are deemed unnecessary and not too urgent to be issued. Indirect efficiency can be done by monitoring product quality more tightly so that the percentage of products with good quality categories can be increased and ultimately have a significant effect on the acceptance of the craftsmen.Efficiency can be done by optimizing the existing production capacity.

- Improve the quality of human resources, skills and training for workers Conduct training for employees to maintain raw materials that do not occur during the production process. So that no product material will be recorded. Likewise, batik results will be better. Good batik results will have an effect on the selling price of the product. For this reason, the workforce continues to be improved in its capabilities and productivity. Besides that, they are also looking for experts because there are few people who can and want to make batik and limitations.

- Developing networking with similar companies, both the same scale and greater The strategy of developing networking with similar companies, both the same scale and greater scale is a strategy developed by the company in the face of considerable market demand.This networking is built based on togetherness, honesty and product similarity, while with larger companies, this strategy is used to build a broader market and maintain products produced by SMEs. 
- Increaseing promotion by making advertisements on the internet the first step that needs to be done with regard to promotion is to make the products that are easily recognizable on the market. This can be done in certain market segments, by introducing product identities that differentiate them from the same products from competitors, for example making attractive packaging with clear craftsman identity. With several advantages of product quality introduced through promotional media, consumers will easily recognize the product in question on the market. Coupled with the existence of the internet, craftsmen can easily promote products evenly online.So that Jambi batik craftsmen can be known; in foreign countries. Like the AZMIAH Jambi batik, the existence of batik has penetrated foreign markets.

- Improveing marketing performance in analyzing market demand the marketing section of a company is likened to the spearhead of the company, where the performance of this section has a real influence on the acceptance of SMEs. The effectiveness of marketing performance can be done with a marketing mix approach by evaluating the extent to which the application of product strategies, prices, promotions and distribution can influence consumers to make purchases. The market share outside Jambi is still very potential to be developed and so is the export market share. If deemed necessary, the craftsman can make changes to marketing strategies that are more relevant to the existing conditions to be able to reach potential market share with the existing price, promotion and distribution approaches, because the products produced are considered good enough and can be accepted in various market segments.. Offer products to organizations or groups of work groups such as schools, private companies or government in serving the making of batik uniforms.

\subsection{S-T Strategy}

The S-T strategy column is a strategy that uses the strength of the company to avoid the threats. Strategies that can be carried out by the company are:

- Give protection to the creativity of Batik products the products produced by the craftsmen always get protection. Especially regarding copyright. Because batik products are easy to imitate. Motives and designs should be patented. so that it can be protected from peeling threats.. Craftsmen's concerns can be overcome if the government provides legal protection assistance for the creation of craftsmen.

- Provide information on quality standards for products to cover the product in order to continue to create good quality, a standard is needed. Information from quality standards can support the sale value of products. Consumers will be more confident and confident in using the product. In addition; the entry of new competitors does not become a heavy problem for craftsmen, if they already have clear quality standards. So that what is expected is the permission to increase consumer interest will be realized. Because consumers want quality products. Batik UKM always prioritizes the quality of the products produced, both in terms of design, color, and variety of shapes or sizes.

- Improve the quality of service to customers customer service is important to pay attention to. Through service that can satisfy customers will have an impact on customer loyalty? In general, customers who come in are difficult to reach homes and craftsmen production sites. Because most craftsmen produce in the alleys and are less visible to visitors. Therefore, the sale of the results of the craftsmen is more focused on the batik studio which is more strategically located. While at the studio itself it opens a little late, and even looks quiet. Therefore, efforts need to be made to increase the utilization of the studio in providing better services to customers.

- Conduct business partnerships this is important to maintain the sustainability of production. Raw materials for example, companies do partnerships with farmers (silkworms) or natural silk craftsmen. In the marketing pattern, companies conduct marketing with various parties, including small traders, medium and large traders, shops and participating in exhibitions carried out by the Industry and Trade Agency, the Cooperative Service and small businesses, KADIN and other relevant agencies.

- Improve models of finished products that are more creative and innovative in general, craftsmen almost have the same motive, even coloring is almost similar. This condition will add to the increasingly severe competition. On the other hand, every craftsman has their own characteristics and virtues. This gives excellence to craftsmen. But consumers have properties that are easily saturated, so that craftsmen need to be more innovative both in terms of design, motives and coloring. Improving products becomes more innovative, 
because generally only sell materials, it is necessary to create ready-made products that are more variant of the model. Especially for women's clothing. Because most craftsmen only provide men's shirt clothes. So that the market for women's products has not been fulfilled.

\subsection{W-T Strategy}

The W-T strategy column is the company's strategy to try to minimize the weaknesses that the company has in avoiding existing threats. The strategies that can be done are:

- Improve regional infrastructure. The condition of the location of the pengajin is mostly across the city, located quite far from the city. And there is a back or side along the Batanghari River. As a means of tourism which is quite good. However, facilities and infrastructure along the river are not adequate.

- Develop policies for developing tourist cities along the Batanghari River as well known the long river is Batang Hari, needs to be managed and reorganized into a pleasant tourist attraction. Starting from the cleanliness of the environment, parks, means of transportation, security, and culinary places.Most of the batik makers come from this area and it is located inside so there needs to be a stand in the area along the river.

- Increase capital by making loans to the government through BUMN (State-Owned Enterprises, SOEs) one of the obstacles to business development is capital. Craftsmen complain that the lack of venture capital makes them difficult to develop. Opening up of rotating funds for business development through cooperation with SOEs.SOEs can hold foster children to promote batik SMEs and soft loans that do not complicate craftsmen.

- Increase the use of promotional media some craftsmen have started promoting products online, even having their own websites. But most of the craftsmen did not promote their products. Coupled with the condition of the craftsmen's house that is not on the side of the road (into the alley).For this reason, the local government has been able to take steps to accommodate the results of the craftsmen to the Batik Studio. But the existence of the studio is still managed not optimally. There needs to be promotions and event events, at least 2 to 4 times a year.This hasn't been done yet. Besides that, there are no banners along the road, which show the batik village area. This is important to be done to provide direction for migrants. Procurement of exhibition fairs.

- Add more dispersed distribution channels this strategy is carried out so that products are widely known by consumers in the face of many competitors and substitute products. This strategy can be done by expanding and enlarging the marketing area, namely by entrusting products to fashion companies, such as factory outlets, boutiques and other companies.

\section{Discussion}

Most of the craftsmen are located in the city of Sebrang Jambi, precisely behind the Batanghari River. Is a gathering place for batik houses which is also a place to live. The craftsmen make batik mostly use garages, residential houses; certain space which is used as a place for the production process until finishing.So the space is very limited. For this reason, many batik processes are also carried out by using freelance employees. Because it is impossible to accommodate large numbers of employees, this condition is related to the limited space / space available in the home of the business owner. The situation doesn't have the garment itself.In an effort to maintain and develop the batik business, Munizu (2010) that the problems of SME development are related to factors and external issues related to aspects of strengths, weaknesses, opportunities and threats to the determination of the development and growth of SMEs Lesceviva (2004).The results of the description and analysis of the strengths, weaknesses, opportunities and threats of batik SMEs that were chosen in the pilot project showed a variety of variations. But almost have the same opportunities and threats. From the results of the SWOT analysis, there are 25 strategies that must be done by SMEs.

\section{Conclusion}

Through the analysis that has been conducted in this study it can be concluded that: Implementation of the strategy management process on the assessment of internal and external factors includes several strategies that need to be done in achieving competitive advantage for UKM Batik Jambi.In the S-O position, there are 7 strategies that must be done for SMEs in conducting competitive business. In the W-O position there are 6 strategies that must be done for SMEs in doing competitive business. In the S-T position. There are 5 strategies that need to be done for SMEs 
in conducting competitive business. In the W-T position, there are 5 strategies that must be done for SMEs in conducting competitive business.

\section{Suggestion}

- Make batik centers a more attractive tourist destination. Because the position of batik centers is very strategic, to become a tourist attraction.

- Enhance the promotion of batik centers, to attract the attention of foreign tourists.

- Develop batik motifs and packaging better.

\section{References}

Barney, J. B. \& Hesterly, W. S. (2006). Strategic Management And Competitive Advantage, Usa: Prentice Hall.

Brad, S. \& Brad, E. (2015). "Enhancing Swot Analysis With Triz-Based Tools To Integrate Systematic Innovation In Early Task Design”, World Conference: Triz Future;

Cojanu, V. \& Bilbor, M. R. (2007). "The Swot Technique In Action: Strategic Analysis Of Development In Romania”, Review Of Management And Economical Engineering, 6 (5), Pp. 162-167.

David, F. R. (2003). Strategic Management-Concepts And Cases, (9th Edition), Usa: Pearson Education.

Kew, J. \& Stredwick, J. (2010). Human Resource Management In A Business Context, Uk: Cipd Lesceviva, M, 2004, Rural Entrepreneurship Success Determinant, Unpublished Working Papers, Faculty Of Economics, Latvian University Of Agriculture, Eksjo, Latvian.

Lexy J. Moleong. 2002. Metodologi Penelitian Kualitatif. Bandung: Pt. Remaja Rosdakarya

Munizu, Musran, 2010, Pengaruh Faktor-Faktor Eksternal Dan Internal Terhadap Kinerja Usaha Mikro Dan Kecil (Umk) Di Sulawesi Selatan, Jurnal Manajemen Dan Kewirausahaan 12,33-41.

Pahl, N. \& Richter, A. (2009). Swot Analysis-Idea, Methodology And A Practical Approach, Germany: Grin Verlag. Pearce, J. A. \& Robinson, R. B. (1991). Strategic Management, (4th Edition), Usa: Irwin, Inc.

Sarbah, A. \& Otu-Nyarko, D. (2014). "An Overview Of The Design School Of Strategic Management (Strategy Formulation As A Process Of Conception)", Open Journal Of Business And Management, 2, Pp. 231-249.

Sevkli, M., Oztekin, A., Uysal, O., Torlak, G., Turkyilmaz, A. \& Delen, D. (2012).

"Development Of A Fuzzy Anp Based Swot Analysis For The Airline Industry In Turkey", Expert Systems With Applications, 39, Pp. 14-24.

Thompson, A. A., Strickland, A. J. \& Gamble, J. E. (2007). Crafting And Executing Strategy-Concepts And Cases, (15th Edition), Usa: Mcgrawhill/Irwin.

Umar H. 2008. Strategic Managementin Action. Cetakan Kelima .Jakarta: Pt Gramedia Pustaka Utama Weihrich, H. (1982). "The Tows Matrix- A Tool For Situational Analysis", Long Range Planning, 15 (2), Pp. 54-66.

Zimmerer, T.W. Scarborough, N.M. \& Wilson, D. (2008). Essentials Of Entrepreneirship And Small Business Management, 5th Edition, Pearson Education Inc, New Jersey. 
